\title{
The Function of Speech Acts in a Vatican II Declaration: Gravissimum Educationis
}

\author{
Toon van Gestel \\ Tilburg School of Catholic Theology, Tilburg University, Tilburg, \\ The Netherlands \\ A.J.A.M.vanGestel@uvt.nl

\begin{abstract}
Fred van Iersel
Tilburg School of Catholic Theology, Tilburg University, Tilburg, The Netherlands

Kees de Groot

Tilburg School of Catholic Theology, Tilburg University, Tilburg, The Netherlands
\end{abstract}

\begin{abstract}
This paper provides an analysis of Gravissimum Educationis, the Vatican II declaration on Christian Education. The paper focusses on speech acts as text signals for an ideal reader within the declaration's communication framework. To date, speech acts have not been scrutinized in Vatican II constitutions, decrees, or declarations. An analysis of performative utterances in Gravissimum Educationis is presented on the basis of J.R. Searle's taxonomy on speech acts. The major finding is that in its speech acts, Gravissimum Educationis, as a Vatican II declaration, stands out from previous ecclesiastical documents. As a new form of Church language, it is innovative and, as such, may fit in well with the panegyric literary genre.
\end{abstract}

\section{Keywords}

Gravissimum Educationis - Catholic Education - Speech Acts - codes taxonomy Panegyric literary Genre

* Corresponding author: Toon van Gestel. 
As a Vatican II declaration, Gravissimum Educationis (1965) is not well known. Nevertheless, its message on education remains worthwhile for our age, for parents and teachers, as well as for Catholics and non-Catholics. The declaration states that the role of parents in education is primordial, while the roles for both Catholic and non-Catholic schools are complementary and adjuvant. Regarding education, parents, schools, Church, and State act as stakeholders in accordance with the principles of subsidiarity and distributive justice. In his Heythrop Conference lecture, Sean Whittle (2017, 23ff.) stands up for Gravissimum Educationis as a source and stimulus for new thinking on Catholic education. In this paper, we follow his stance by reading this declaration anew, with a fresh look, while posing the question: Can a new reading yield hidden treasures and previously unseen or forgotten insights?

\section{The Reception and Readings of Gravissimum Educationis}

Readers' reception of Gravissimum Educationis was troublesome and meagre from the start, particularly because this declaration was the result and end of a process of a rather conflictual conception. The differences of opinion about the concept of the Catholic school and its implications for child rearing and education-Catholic, Christian or in general-had not been solved. Explanations have been sought in the conflictual origins of the declaration and, subsequently, in its inconsistencies (Hendriks 1986, Hilger 199o, Siebenrock 2005). Ultimately, in the final text, a switch was made from the Catholic school concept specifically to the broader concept of Christian education and humane upbringing and schooling, which is noticeable in the headings and division of sections. Throughout the declaration, the focus shifts from education in general to Christian education, and from the school in general to the Catholic school (Hilger 1990, 63-76). The first four sections deal with Christian and Catholic upbringing and education, including humane upbringing (Sections 1-4); the next five are about the (Catholic) school (Sections 5-9); the last three sections discuss higher (Catholic) education (Sections 10-12).

High-profile theologians in the 196os, such as the Dutch-episcopal adviser Edward Schillebeeckx (1964) and peritus Joseph Ratzinger, the later Pope Benedict XVI (2009), read Gravissimum Educationis as systematic theologians and, therefore, a more practical-theological approach seems preferable. Like the pastoral constitution Gaudium et Spes, the declaration was to be seen as 
a vision disquisition meant to be elaborated upon in follow-up documents regarding practical acting in Church and world. During the years following Vatican II, the Congregation of Catholic Education consequently published a considerable number of declarations, the first of which was The Catholic School (1977). In a broader historical context, it can be established that Karl Rahner's Manual of Pastoral Theology (Franz Xaver Arnold et al., 1972), which he wrote with other scholars, changed the way the Vatican II declarations were studied. Up to that point, declarations were commented on from the angle of exegesis, patristics, or systematic theology. However, after Rahner's Manual, they were studied from a practical-theological perspective.

Our method has been used in practical theology before. Dutch practicaltheologians such as Van der Ven $(1993,51-65)$ addressed the use of languagephilosophical instruments, ${ }^{1}$ while Hermans et al. (2002) applied linguistic methodology in their research. In the hermeneutically-oriented approach to practical theology, literary, linguistic, and semiotic analyses of texts have been applied in addition to the methods of social science disciplines such as sociology and psychology. The Dutch practical-theologian Dingemans (1996, 36-57) characterizes religious communities, on which practical theology focuses its thinking and acting, as 'interpretation networks.' ${ }^{2}$ The council text Gravissimum Educationis and its follow-up texts, viz., the post-conciliar declarations on Catholic education by the Congregation of Catholic Education, function as direction indicators and sources of inspiration in this cultural network. However, the reception and appropriation of these have become troublesome in the later years following Vatican II. In European society, the Christian perspective has become problematic because of secularization, more specifically, 'de-traditionalization, individualization and pluralization.' Confessional schools nowadays experience 'contemporary limitations and the counterproductive effect of Christian values education.' An overly religious interpretation of generally human values in a Christian sense makes young people averse (Boeve 2014, 197-202). Nevertheless, relatively recent research proves that upbringing in Christian values, also among young people, remain popular, at least in its secular interpretation (Pollefeyt \& Bouwens 2010).

Although our method is broadly accepted in practical theology, the findings about official declarations concerning religious policy are rarely scrutinized

1 Describing a.o. the conative tools in religious communication: adhortatives, e.g. invitations, encouragements and declaratives, e.g. condemnations, appointments etc.

2 In addition, Dingemans distinguishes two more pragmatic approaches that deal with pastoral care, the empirical-analytical and political-theoretical, respectively. 
from a linguistic communicative perspective. One example is the extended analysis by the Dutch theologian, Albert Jan Stam, of performative language in three declarations of the World Council of Churches' Faith and Order Commission (2008). In this paper, we aim to analyse the speech acts in Gravissimum Educationis on the basis of the taxonomy of speech acts developed by the American language philosopher J.R. Searle (1976, 1990) who, in turn, based his taxonomy on the five categories of performative utterances developed by his Cambridge professor, J.L. Austin (1975). From an epistemological point of view, this speech acts model anticipates the postmodern pursuit of performativity in the scientific discourse (Boeve, 2014, 59). First, we sketch the model of performatives developed by Searle and his learned master Austin. Then, for the purpose of this investigation, we proceed with our supplemented design of Searle's taxonomy on speech acts. Subsequently, we apply the performative categories of this taxonomy to the (sub-)sections of the declaration. We draw some provisional conclusions and, finally, we offer a brief sketch of the literary genre under which Vatican II declarations might be characterized, which, when compared with conciliar declarations since The Council of Trent (1545-1563), may be considered new.

In the philosophy of language and linguistics, an important issue is the variety of ways language is used. According to J.R. Searle, a speech act is a decisive entity in human communication. Elaborating on the ideas of his tutor J.L. Austin, Searle developed his taxonomy of speech acts on the basis of semantic differences, which are being constructed grammatically in the language expression or utterance (Searle 1976). Austin (1975) had coined the pragmatic-linguistic distinction between sentences and linguistic utterances in his pioneering book, How to do things with words. Sentences are grammatical constructions consisting of a subject and a predicate, by which a certain state of affairs is expressed. Linguistic utterances implicate a so-called illocutionary purport: an appeal is made to the reader/listener, or the speaker commits her/himself to a certain action or behaviour. These illocutionary utterances aim to effect something specific in the state of mind and behaviour of the sender or receiver-one's views, one's mentality, one's acting. These performatives may be 'happy or unhappy', viz., accepted or not by the receiver. Furthermore, they must be apt to the situation and circumstances of the people to whom they are addressed (Austin, 1975, 25-38). Linguistic utterances not only have formal features but 
also functional qualities and faculties. These have to do with the communicative roles of author and reader, speaker and listener in communication terms: sender and receiver. ${ }^{3}$

After Searle had found that Austin's grouping of these illocutionary utterances - his famous performatives-types - showed inconsistences, he discerned illocutionary verbs from illocutionary acts, (Searle, 1976, 7-10). The latter he called speech acts. The former group contains verbs that aim at a certain speech act, knowingly or unknowingly, explicitly or implicitly. ${ }^{4}$ These verbs label the function (F) of the propositions (p) that form their content: $F(p)$. The taxonomy contains five categories, outlined below, on the basis of divergent sorts of illocutionary verbs. Searle made his distinctions on the basis of a dozen criteria that he called dimensions. The three most important dimensions are:

1. Differences in the point (or purpose) of the (type of) act:

The sender instigates (or tries to achieve) the receiver or sender to 'do' something mentally or by acting. This dimension is shared by all five categories mentioned below and forms the most basic part of them, but they may differ in their so-called essential conditions (Searle 1990, 54-71, Austin 1975, 12-38). The point or purpose of a promise is something different than those of a command.

2. Differences in the direction of fit between words and world:

a. Words to world; $\downarrow$ Example: a description is a representation - true or false- of how something is.

The speech act aims at a correct display of a state of affairs: representatives.

b. World to words; $\uparrow$ Example: a command aims at changing a specific state of affairs.

The speech act intends to bring into line a state of affairs in reality with the enclosed proposition: declaratives, directives.

3. Differences in expressed psychological states: the sincerity condition. ${ }^{5}$ The sender expresses a specific conduct, attitude, or intention regarding the propositional content of his/her utterance.

3 Cf. Communication Model: Sender-Receiver

4 Speech acts are comprised in the message mostly implicitly. Sometimes, however, they are pronounced explicitly, e.g., in utterances, sc. speech acts like: I swear to tell the truth. Herewith I promise to help you. Austin labelled the unmarked speech act as indirect utterances; the marked speeches acts he called explicit utterances.

5 Id. 


\section{a. Commissives; $\rightarrow$}

The sender commits to a certain attitude, act, state, etc. regarding the propositional content. One actually commits oneself to something, e.g., a promise made. Example: I promise I will come to join you.

b. Expressives; $\leftarrow$

The sender expresses a certain attitude, state, etc. to the propositional content. One actually means what ones says, e.g., thankful words to someone who has helped in some way. Example: I thank you for giving me this opportunity.

4 Searle's Speech Acts Taxonomy Amplified and Applied to Gravissimum Educationis

\begin{tabular}{|c|c|c|}
\hline Speech acts & Code & Verbs \\
\hline Representatives & $\operatorname{Fre}(\mathrm{P})$ & $\begin{array}{l}\text { Claim, describe, assume, explain, tell, (re) argue, } \\
\text { specify, deny, \&c. }\end{array}$ \\
\hline Directives, type I & Fdi.pre(P) & $\begin{array}{l}\text { Command, warn, forbid, entitle, prescribe, } \\
\text { purport \&c. In addition: ought-utterances like } \\
\text { must, should, ought \&c. }\end{array}$ \\
\hline Directives, type II & Fdi.app $(\mathrm{P})$ & $\begin{array}{l}\text { Request, invite, invoke, exhort, advise, encourage, } \\
\text { recommend \&c. }\end{array}$ \\
\hline Commissives & $\mathrm{Fco}(\mathrm{P})$ & $\begin{array}{l}\text { Promise, commit, guarantee, threaten, entrust, } \\
\text { blackmail, connect, \&c. }\end{array}$ \\
\hline Expressives, type I & Fex $/-(\mathrm{P})$ & $\begin{array}{l}\text { Disapprove, condone, complain, regret, \&c. } \\
\text { In addition: implicit as emphatic language }\end{array}$ \\
\hline Expressives, type II & $\mathrm{Fex} /+(\mathrm{P})$ & $\begin{array}{l}\text { Judge, praise, compliment, thank, \&c. } \\
\text { In addition: implicit as emphatic language }\end{array}$ \\
\hline Declaratives & $\operatorname{Fde}(\mathrm{P})$ & $\begin{array}{l}\text { Condemn, acquit, baptize, marriage, open } \\
\text { or close (e.g. a meeting), contract, dissolve, } \\
\text { terminate, break up, \&c. }\end{array}$ \\
\hline
\end{tabular}

\subsection{Elucidation I: Coding}

Searle's original five types of speech acts are amplified by us in this respect so that further distinctions are made regarding directives and expressives. 
This is also the case for the corresponding codes of the five types (Searle, 1976, 10-16):

- $F$ labels the functional aspect of the performative utterance or illocutive speech act. This may be explicit or implicit, as noted above.

- $P$ indicates the propositional content of the speech act. The sequence of subject-predicate shows in a logical way the factual or supposed state of affairs.

- re, di, co, ex, de mark the category of the illocutive utterance, as explained below.

- pre, .app, /-, /+ label a certain specification, as explained above.

The last-mentioned category, Declaratives: $F d e(P)$, is more or less in line with the type of utterance that Austin triggered to enfold his theory on speech acts: viz., the performative utterance, which actually changes reality, e.g., the baptizing of a child. A classic example of a declarative is a marriage vow.

Another famous-yet debated - performative utterance is the consecration formula for the purpose of transubstantiation. Pope Benedict XVI declared in his encyclical Spe Salvi that the Christian message in the gospels is not only informative but also performative: the Gospel makes things happen and changes the lives of persons (2007, Section 2).

\subsection{Elucidation II: Five Types of Illocutionary Acts}

We are analysing Gravissimum Educationis on the basis of five types of illocutionary acts, which are discerned and refined below (Searle 1976, Searle 199o, 54-96, Austin 1975, 148-164). ${ }^{6}$ From this perspective, all five categories resemble each other in so far as the sender exhorts the receiver or oneself to do something or not to do something. However, the categories differ in the specific character or type of this act. Searle calls this 'the dimension: differences in the point (or purpose) of (the type of) act' (1976, 2-4). The categories and subcategories are outlined below:?

- Representatives, $\operatorname{Fre}(P)$ : With these verbs the sender represents a state of affairs in the world, by which the sender wants to draw the attention of the receiver, in order to influence the receiver's perspective on the world around him/her. The propositional content represents the state of affairs in the world. We connect to this category Searle's Dimension, 'word-to-world direction of fit': this speech act intends to offer a correct representation of a state

6 Austin distinguished five classes of performatives that are more or less analogues to Searle's categories, viz., verdictives, exercitives, commissives, behabitives, expositives.

7 This suits the purpose of a first pragmatic linguistic analysis of Gravissimum Educationis. Thanks to prof. dr. H. de Swart for his comment and advice. 
of affairs, labelled by us with $(2 A \downarrow)$. Example: In the Netherlands, church attendance has diminished by 70 per cent over the last 50 years.

- Directives: The sender wants to incite, urge the receiver to do or not do something. To this category we apply Searle's Dimension 'world-to-word direction of fit' $(2 \mathrm{~B} \uparrow)$. By means of this speech act the sender intends to bring in line a state of affairs with the enclosed propositional content. We divide this category into two divergent types, which represent opposite climates of thought:

- Directives of the prescriptive type: Fdi.pre $(P)$, example: I forbid you to come home late. (Said by a mother to her child.)

- Directives of the appealing type: Fdi.app $(P)$, example: I invite you to join me for dinner this evening. (Said by a host to his guest.)

According to the first prescriptive-directive type, the Church states how the reality of this world actually is determined and what one as a reader should do with or how one should act according to this (new) knowledge. The second appealing-directive type fits in the modern spectrum of making one's own choices and taking self-responsibility. In this case, the Church encourages, appeals, invokes, etc.

- Commissives, Fco $(P)$ : By means of this type of performative the sender commits oneself to do or not to do a certain act. To this category we connect Searle's Dimension, 'sincerity': Differences in expressed psychological states, which we label as Commissives $(3 \mathrm{~A} \rightarrow)$ : the sender expresses a specific attitude or intention regarding the propositional content of his/her speech act, in the sense that $\mathrm{s} /$ he incites or commits him/herself to a certain act towards the recipient. In this case, the Church first commits itself instead of giving orders to others, etc. Example: I promise to come join you for dinner. (Said by the guest to his host.)

- Expressives: By means of this type of performative the sender expresses his/ her feelings, attitudes, ideas, etc. regarding a specific propositional content. We combine this category with Searle's Dimension, 'sincerity': Differences in expressed psychological states. We label it with Expressives $\left({ }_{3} \mathrm{~B} \leftarrow\right)$ : the sender expresses a specific attitude or intention regarding the propositional content of his/her utterance in this sense that s/he gives voice to his/her appreciation or disapproval to the receiver. Just like the category of Directives, we distinguish Expressives into two types.

- Expressives, Fex/-(P): with intuitively a more (in formal perspective) negative meaning content and connotation, example: I regret my behaviour towards you last night. (Said by a boy to a girl.)

- Expressives, $F e x /+(P)$ : with intuitively a more (in formal perspective) positive meaning content and connotation, example: I thank you for 
the beautiful flowers you gave me last Mother's Day. (Said by a mother to a son.)

In this context, we like to point to the conspicuously frequent emphatic language use in Gravissimum Educationis, which means to contend or declare something with bias and emphasis, and either condoning or advising it, etc. Gravissimum Educationis, in our opinion, is rather typical in this respect. Biased utterances or sentences can be found in practically every section. In this case, the Church encourages, appeals, invokes, etc., thereby enthusing the reader through its message.

- Declaratives, Fde $(P)$ : By this type of speech act-the famous performative utterances of Searle's tutor Austin - the sender brings into line a state of affairs in the real world with the propositional content of his/her declarative speech act; in other words: $\mathrm{s} /$ he changes the world by his/her words. This category fits in Searle's Dimension 'world-to-word direction of fit' $(2 \mathrm{~B} \uparrow)$. This speech act aims to bring in accordance a specific state of affairs with the enclosed propositional content. Example: I hereby declare you man and wife. (Said by a priest to a couple.)

\section{5 Speech Acts and Codes in Gravissimum Educationis, an Analysis ${ }^{8}$}

The conciliar declaration Gravissimum Educationis may be distinguished into a more generic part about Christian education (Sections 1-4), and one specific part about the Catholic School (Sections 5-9) and Catholic Higher Education (Sections 10-12). Both parts together are preceded by an Exordium and an Introduction, and followed by a Conclusion, References, and Notes. We analysed Gravissimum Educationis on the basis of the above elaborated five types of illocutionary acts. In our result-description we concentrate on Sections 1-12, which form the content part. We follow the structure of the table of speech acts above. First, however, we present some findings about Gravissimum Educationis in general, the Exordium and the Introduction. We conclude this section with some findings in regard to the Conclusion, References, and Notes.

\subsection{Gravissimum Educationis: $\operatorname{Fde}(\mathrm{P})$, Fre(P)}

As a conciliar declaration, one might say Gravissimum Educationis as such, forms a declarative ${ }^{9}$ illocutionary utterance. Therefore, we find in every section the code: $F d e(P)$. Equally present is the code $\operatorname{Fr}(P)$, because every utterance

8 Cf. Hyperlink Appendix.

9 This may seem tautological, but it is meant in the Searlian way of course. 
contains a propositional content, in whole or in part. ${ }^{10}$ This code represents a description and, subsequently, a claim.

The declarative illocutionary utterance is a performative language construct that is striking, and the one Austin originally had in mind. The Dutch communication linguist, Antoine Braet (2000), coined this category as institutespecific because the Church as a societal organisation is qualified to publish these kinds of declarations, in the same way a judicial power is authorised to pronounce and impose a sentence on a perpetrator. As a result of the declarative (sentence) in this latter case, the real life of the perpetrator is changed, either as an acquitted suspect and thus free civilian, or as a condemned perpetrator sentenced to punishment (Braet 2000, 68-73). In an analogous way, by means of their declaration, the council fathers intended to change the reality of faith for Christians, and according to the Church itself, the lives of all people. Whether this speech act was 'happy or unhappy' (Austin 1975, II: 12-24, III: 2538 ) was a matter of debate in the post-conciliar period. Regarding the socially critical function of practical theology (Dingemans 1996, 49-53), it is worth noting that shortly after Vatican II the Magisterium was criticized by Latin American liberation theologians because they perceived that the historicalcontextual inequality in their societies was neglected (Guttiérez 1989, 105-142). The Vatican II documents as declaratives seemed not to be apt to the socioeconomic circumstances of the people to whom they were addressed (Austin 1975, II: 12-24, III: 25-38). The famous and critical CELAM-conferences of the Latin-American bishops enthusiastically accepted the freedom of interpretation of the council documents which, in the 1980 os in particular, led to great tensions with the Vatican (Madero 2018). By the declarative speech act, the conciliar fathers aimed to redefine the reality of children, youth, and parents: their contemplations were brought into correspondence with their words in the declaration. It is for this reason that they refer in a note in the Introduction of Gravissimum Educationis to the Universal Declaration of the Human Rights, whereby the United Nations in 1948 altered the political reality of the world citizen. In 1959, the United Nations continued with their Declaration of Rights of the Child. ${ }^{11}$ In what follows we will scrutinize the text in order to unveil its speech acts. The illocutionary verbs are marked in italics.

10 There are speech acts that only contain a part of a proposition, e.g., in the case of an imperative such as: 'Go!' Here we only see a verb. Another example is a warning with only the word: 'Dog!' Here we only have the subject.

11 In his encyclical Pacem in Terris, Pope John Xxin (1963) initiated the Church's global perspective on human rights. 


\subsection{Exordium: Fde(P), Fre(P)}

The Latin version of the declaration (Gravissimum Educationis 1965, Latin) contains a cliché and this figure of speech is quite remarkable: the holder of the highest office of the Roman Catholic Church, Pope Paul vi, calls himself: 'Servus servorum' (the servant of God's servants). This is a modesty topos, ${ }^{12}$ which, by way of support of the declarative speech act, aims at effectuating the opposite.

The Pope's high rank is accentuated by the following words in the preamble: 'Una cum sacrosancti concilii patribus' (together with the fathers of the holy council). Besides the episcopal collegial aspect that resonates in 'together', the Pope stands out from the council fathers, to which he himself obviously does not belong (cf. Ratzinger 1966, 45-72). ${ }^{13}$

\subsection{Introduction (Prooemium)}

The Church commits ${ }^{14}$ itself to the eminent relevance of education and schooling in modern times because of the social and technological developments in which persons as civilians claim their societal participation, $\mathrm{Fco}(\mathrm{P})$. The very first three words of the declaration sound like the stroke of a gong: gravissimum educationis momentum, Fex/+(P).

Subsequently, the council fathers describe a state of affairs regarding the upbringing and educating of children and announce why they raise this issue, starting with the right to education in general and Christian education in particular (cf. Stockman 2015, 127-133), ${ }^{15}$ Fre(P). The changed societal state of affairs evokes an appeal on the Church committing it to deliver its share by determining its new point of view, Fdi.app $(\mathrm{P}), \mathrm{Fco}(\mathrm{P})$. However, first the Church commits itself to proclaiming, 'the mystery of salvation to all men and of restoring all things in Christ', according the mandate it has received from Christ, Fco $(\mathrm{P})$, Fde $(\mathrm{P})$. Certain principles are formulated that need more elaboration and by which, at the same time, a promise is made to install a special postconciliar commission for further elaboration, $\operatorname{Fre}(\mathrm{P}), \operatorname{Fco}(\mathrm{P}) .{ }^{16}$

12 A topos modestiae (lat.] is a cliché from the classical rhetoric. Cf. Claes \& Hulsens, 2015,138 .

13 The references are meant both as support of my analysis, as for further reading.

14 Illocutionary verbs and nouns that form indication for implicit speech acts in italics.

15 The Belgian scholar and friar René Stockman point in this respect at the inclusive and exclusive aspect of Catholic education as presented in Gravissimum Educationis, as elaborated especially in paragraph 9 . This would become the Congregation for Catholic Education. 
An assessment of adjectives and adverbs indicates an emphatic expressive aspect of the Introduction, and actually throughout the declaration. It includes a relatively large number of these, which express a certain degree of urgency: exceptional (lat.: gravissimum), urgent (lat.: urgentior), more and more (lat.: magis magisque), amazing (lat.: mirabile (s], fast rise (lat.: celeriter crescente), etc. We code these kinds of adjectives and adverbs as expressive, Fex/+(P), Fex/-(P).

The declaration goes on to comment on aspects of education that are of interest to the Church, enumerating these in twelve sections. We will offer not so much a critical-empathic reading (Boeve, 2014, 99-102) of these sections but, instead, we will concentrate mainly on the frequency and combinations of relevant speech acts and the accompanying codes. For the content-representation, we refer to the Appendix, which, however, is not exhaustive.

\subsection{Representatives}

In the content part (Sections 1-12), representatives are frequently applied for claims regarding a state of affairs in the world. In doing so, the Church, as a sender, aims to convince the believer, as a receiver, of the accuracy of its world view. The universal right to education and the rights and obligations concerning Christian education and its implications for the Christian believer are denoted and subsequently claimed, $\operatorname{Fre}(\mathrm{P})$, as being the case. As stated above, every speech act contains a propositional content, which may also be labelled as a representative.

\subsection{Directives}

A claim is usually accompanied by a directive, either an appeal, Fdi.app $(\mathrm{P})$, or a prescript, Fdi.pre(P). Directives incite, urge the receiver to do or to leave something, either as compelled or by consent. The appealing type, Fdi.app (P), dominates over the prescriptive one, Fdi.pre( $\mathrm{P})$. Appealing directives regard exhortations and appeals for involvement or commitment in an ambiance of cooperation. The Church inclusively (cf. Stockman 2015, 132-133) calls on stakeholders, including State and civil society, to help with school organisation and design, with special attention to the under-privileged and non-believers, Fdi. app $(\mathrm{P})$. Since Vatican II is a laity council (cf. Apostolicam Actuositam 1965), in addition to parents as first stakeholders in education (cf. Leckey, 2006, 1-21), both political and church officials are also exhorted, Fdi.app(P), to make possible and maintain moral and religious education for all children in accordance with the subsidiarity principle (cf. Cattaro \& Russo 2015, 29-44). In reference to former state-church differences, and even conflicts about education, these appeals for cooperation are striking. 
The principle goals of Christian education are specified in a number of aspects, Fre $(\mathrm{P})$, which, at the same time, are encouragements, Fdi.app $(\mathrm{P})$, instead of prescripts, Fdi.pre(P). Priests are exhorted, ${ }^{17}$ Fdi.app(P), instead of commanded, Fdi.pre $(\mathrm{P})$, to create conditions and implement for all Christians, and youths in particular, their right to Christian education. The relatively frequent use of the prescriptive speech act, Fdi.pre(P), in, e.g., paragraph 3 is not surprising because the educational obligation of parents, the ordained, and lay-teachers regards the tradition of the Christian doctrine of faith.

Within the historical context of the church-state controversy regarding Christian education and Catholic schools, paragraphs 5-9 may be perceived as the heart of the matter. The frequency of appealing directives, Fdi.app $(\mathrm{P})$, and commissives, $\mathrm{Fco}(\mathrm{P})$, instead of prescriptive directives, Fdi.pre $(\mathrm{P})$, in these sections is conspicuous. Prescriptive directives here are applied to claims and demands against the State. Both the Church and parents are entitled to establish and administer Catholic schools (cf. Dignitatis Humanae 1965, section 2-7; Briel 2008, 385). While having an inalienable right and duty to educate, parents claim a freedom of school choice for their children, which should be supported and facilitated by the State (cf. Stockman 2015, 129-130; Deus Caritas est 2005, sections 26-31), Fdi.pre(P).

\subsection{Commissives}

Commissives are applied in cases of promises, involvements, commitments, or warrants regarding the implementation of education. Mostly they occur in combination with or in relation to one's own goals previously set. In caring for the moral and religious education at non-Catholic schools (cf. Cattaro \& Russo 2015, 22-24), the Church promises the deployment of priests, teachers, and also fellow students, Fco(P). The Church expresses its commitment to dialogue (cf. Boeve 2015, 358-379), Fco(P). The Church (finally ${ }^{18}$ ) commits itself as a societal organisation in the education of people of other convictions and beliefs (cf. Unitatis Redintegratio 1964, 10-12), Fco(P).

In pursuing of the legitimacy of Catholic universities and Catholic faculties (cf. Sapientia Christiana 1979; Ex Corde Ecclesia 1990), Fco(P), the Church, by way of directives, instruct these to deepen and spread the Christian heritage and to speed up dialogue with separated fellow Christians and non-Christians (cf. Boeve 2014, Perfectae Caritatis 1965, sections 10, 24), Fdi.pre(P).

17 Exhortations in this respect may have a coercive connotation.

18 Gravissimum Educationis conspicuously uses the word 'finally' (Lat.: demum'] to mark the position of the Church as a stakeholder in the authorship of Christian education and every time preceded by state or civil society. 


\subsection{Expressives}

By means of the performative expressive, the sender expresses his/her feelings, attitudes, ideas, etc. regarding a specific propositional content. Often an expressive, negative or positive, accompanies a claim to the State. The Church, e.g., stipulates the exclusion of any kind of school monopoly. A State's monopoly in schooling is rejected, for this is contrary to the natural rights of the human person and to pluralism in many societies, Fex/-(P). On the other hand, positive expressives are reserved, e.g., in cases of praise for the government. The Church, e.g., praises the authorities that guarantee religious freedom and facilitate material conditions for the realization of religious education in all schools, Fex/+(P).

In cherishing the foundation and implementation of higher education, Fex/+(P), the Church recommends and makes appeals to stakeholders, especially those from newly independent States, to promote and foster cooperation between faculties and between universities, national and international, between Catholic schools and non-Catholic schools, Fdi.app(P).

\subsection{Declaratives}

This speech act category aims to bring a certain state of affairs to a sacred level. The Sacred Synod declares the work of teachers as a vocation and an apostolate (cf. Banning \& Borgman 2015), Fde(P), and is the only explicit declarative in the actual content of Gravissimum Educationis, apart from the ones in the Exordium and Conclusion. As indicated above, Gravissimum Educationis as declaration as such, forms a declarative as a whole.

\subsection{Conclusion (Conclusio)}

Quite in line with the previous style of speech acts, some encouragements and words of thanks are expressed.

Topos promulgationis: ${ }^{19}$ After obtaining agreement with the text of Gravissimum Educationis of the Council Fathers, Pope Paul vi gives his approval by fixed ordinance' by virtue of his apostolic authority and order (Lat. Iubemus] promulgation $=\mathrm{Fde}(\mathrm{P})$.

\subsection{References and Notes}

All but one of the references and notes refer to ecclesiastical documents such as encyclical letters, etc. Thus, as 'self-referring' (McHugh 2008) to a very large extent, one may consider this declaration also as an implicit directive speech act $=$ Fdi.pre $(\mathrm{P})$.

19 Quote from the Latin and Dutch versions; this text passage is missing in the English translation. 
In Gravissimum Educationis, instructions on education and upbringing are explicit by text and speech acts, but also implicit by concealed clues. By presenting things in this way, praising, committing or making promises, the reader is also moved in a certain direction. It is precisely these language acts that stand out. As far as the directives in the declaration are concerned, they are both prescriptive and appealing to a good attitude. Furthermore, the Church commits itself to something in almost every section, instead of asking or even demanding something from others. We consider the declarative speech act to be most characteristic. Most remarkable is not this declarative nature of the language used in itself, but the lack of strictly legal prescriptions in this declaration, which is proven by the frequent use of provocative and appealing language. Since Gravissimum Educationis is a future oriented policy document, this characteristic should be interpreted as an indication of a loss of governmental power of the Church as well as an appeal to take over policies on the basis of arguments instead. As a declaration (iuxta constitution, decree) of the Second Vatican Council, Gravissimum Educationis intended to bring about a fundamental change in the lives of not only Catholics, but also other Christians, even other-believers and non-believers - again a social group over which the Church does not exercise power. This explains the language modes we found. As Vigotsky (1986: 256) states: 'The word is a thing in our consciousness, as Ludwig Feuerbach put it, that is absolutely impossible for one person, but that becomes a reality for two. The word is a direct expression of the historical nature of human consciousness.' Thus, it becomes clear that the meaning of expressions used in Gravissimum Educationis is thoroughly relational by nature; it derives its meaning not only from the one who utters the language, but from the one who has to be convinced not by a power based authority, but by argument.

All in all, the speech acts (as labelled by the above-noted codes) show a council declaration of the Church with doors open. Because of its often emphatic wordings, the language may be called enthusing. By their performative utterances, the council fathers seem to be more approving than disapproving. With some regularity, they express promises and the like in which the Church commits itself to something; by doing this, it does not place itself above the Christian believers, other believers, or non-believers but, rather, beside them. There is clearly mention of a horizontal use of language here.

After fifty years, the query is whether the message of Gravissimum Educationis may be called successful, and whether the intended changes expressed by its speech acts have been achieved. In this type of research of textreception, researchers ask the question which elements from the text should 
or could be appropriated by the reader, casu quo policy makers, and policy implementers. This appropriation of new cognitions is instigated by the speech acts in the original text of Gravissimum Educationis. Its propositional contents regarding knowledge and acting are to be found in the follow-up statements of the Congregation of Catholic Education and the circular letters of the bishop conferences about education and upbringing. This paper functions as a starter for research in a language-pragmatic perspective on official Catholic Church documents like encyclicals, constitutions, decrees, and declarations. In this essay, we have focussed on the text of origin itself. Further research is needed into the reactions on this text in the follow-up declarations of the Congregation of Catholic Education.

Epilogue: A New Sound, a New Literary Style?

Although Gravissimum Educationis is generally considered to be in line with its predecessor Divini Illius Magistri (1929), to which it frequently refers, there are also differences. The former contains several new perspectives and elements, and the tone is more positive (Briel 2008, 383-396). According to the American renaissance historian O'Malley, the literary genre of the council, especially in the four constitutions, is the so-called ars laudandi, the panegyric style template $(2008,43-52 ; 1979,36-77)$. This originally classical, pre-eminently literary genre was reinstated by the humanists in the Renaissance and at the time by Vatican priests in their sermons. O'Malley finds it remarkable that the Church had re-adopted this rhetorical style. In the panegyric style format, an ideal image is sketched for which the reader has to be enthused. This is not prescriptive but inviting in style: Look at how beautiful our faith is! The language does not have the behaviour of the believer in mind; rather the inner self of the believer is the target. The language aims at one's spiritual turnaround, one's metanoia. According to O'Malley, the preceding councils of Trent and Vatican I had offered a different picture and sound: these council documents had been drawn up in classicist, legal-legislative terms; the language was 'vertical', in which there is a relationship of authority between author(s] and reader, instead of 'horizontal', in which there is a sense of equality as partners. After all, in the constitution Lumen Gentium (1964, Section 10), all baptized are declared as priests. Above we mentioned already the horizontal style of Gravissimum Educationis.

The style of the Second Vatican Council differs from Vatican I. The documents do not form a static whole, but a dynamic starting point. Gravissimum Educationis is not even finished: the Introduction's last clause states that the 
declaration declares certain (sic!) principles (Lat.: quaedam principia declarat) that are to be developed further on after Vatican II, which is both a testimonium paupertatis and an expression of its dynamics. ${ }^{20}$

The Second Vatican Council was often the scene of protracted and lively debates, which nevertheless led to agreements that breathed a spirit of dialogue: inviting to conversation instead of verbal struggle (O'Malley 2008, 269270, 276-277). This may be called a daring piece, if one takes into account that the number of participants in the council, council fathers and periti, advisers, and guests was very large, certainly compared with the preceding councils (Ratzinger, 2009, 29-30). ${ }^{21}$

\section{References}

'Gravissimum Educationis'. 1995. In: Constituties en decreten van het $2 e$ Vaticaans oecumenisch concilie. Leusden, Stichting Ark: p. 227-241.

Arnold, Franz Xaver, e.a. 1972. Handbuch der Pastoraltheologie : praktische Theologie der Kirche in ihrer Gegenwart (1964-1972]

Austin, J.L. 1975. How to do things with words. Second Edition J.O. Urmson and Marina Sbisà (Eds.). Cambridge, MA: Harvard University Press.

Bill W.J.M. Banning, Erik Borgman, 2015. Leraren, wat boeit jullie? Theoretisch en empirisch onderzoek naar roeping binnen het professioneel zelfverstaan. Antwerpen, Apeldoorn: Garant.

Benedict xvi. Spe Salvi. http://w2.vatican.va/content/benedict-xvi/en/encyclicals/ documents/hf_ben-xvi_enc_20071130_spe-salvi.html (2007).

Boeve L. 2014. Theologie in dialoog. Op het kruispunt van universiteit, kerk en samenleving. Over dialoog, verschil en katholieke identiteit. Kalmthout: Pelckmans.

Boeve L. 2015. 'Scholen van dialoog in liefde-Kruisbestuiving tussen Gravissimum Educationis en Perfectum Caritatis anno 2015'. In: Tïdschrift voor theologie. 55/4. Amsterdam: Boom.

Bosschaert. D., De Mey, P., Lamberigts, M., Schelkens, K., Tercic, H., Witte, H. (2019). Vaticanum II Conciliedocumenten. Latijnse tekst en nieuwe Nederlandse vertaling. Antwerpen / Baarn: Halewijn / Adveniat.

Braet, A., ed. 200o. Taalbeheersing als communicatiewetenschap. Een overzicht van theorievorming, onderzoek en toepassingen. Bussum: Uitgeverij Coutinho.

20 Gravissimum Educationis, Introduction.

21 In total, there were more than 3 ,ooo participants. 
Briel, D. (2008). 'The Declaration on Christian Education': Gravissimum Educationis. In M. Lamb \& M. Leavering (Eds.), Vatican II: Renewal within Tradition (pp. $3^{8} 3^{-}$ 396). Oxford: Oxford University Press.

Cattaro, G., \& Russo, C. (eds.) (2015). Gravissimum Educationis: Golden Opportunities in American CatholicEducation 50 years after Vatican II. Lanham, USA: Rowman \& Littlefield Publishing.

Claes, P. \& Hulsens (2015). Groot retorisch woordenboek. Lexicon van stijlfiguren. Nijmegen, Van Tilt.

Congregation for Catholic Education. 1977. The CatholicSchool. http://www.vatican .va/roman_curia/congregations/ccatheduc/documents/rc_con_ccatheduc_doc_ 19770319_catholic-school_en.html.

De Pater, W.A. 1972. Filosofische taalanalyse in Engeland na 1900. Een overzicht. Cahiers van het Leuvens Post-universitair Seminarie voor Wijsgerige en Fundamentele Pedagogiek onder redactie van C.C. De Keyser en M. Hellemans. Leuven: Uitgeverij Acco.

Dingemans, G.D.J. 1996. '2. Praktische theologie als wetenschap.' In: Manieren van doen: Inleiding tot de praktische theologie. Kampen, Kok: pp. 36-57.

Gutiérrez, G. 1989. Theologie van de bevrijding. Nieuwe editie, vierde, herziene en aangevulde druk. Baarn: Ten Have.

Hendriks, J.W.M. 1986. De katholieke school. De ontwikkeling van het kerkelijk denken over het katholiek onderwijs van concilie tot codex. Brugge: Tabor.

Hermans, C.A.M., ed. 2002. Social Constructionism and Theology. Leiden etc.: Brill.

Hilger, P. 1990. Das Recht auf christliche Erziehung: eine Untersuchung der Genese von "Gravissimum educationis" im Hinblick auf can. 217/CIC 1983. Rome: Pontificia Universitas Gregoriana, Rome.

John XXIII, 1963. Pacem in Terris. http://w2.vatican.va/content/john-xxiii/en/encycli cals/documents/hf_j-xxiii_enc_11041963_pacem.html (1963).

John-Paul II, 1979. English: http://w2.vatican.va/content/john-paul-ii/en/apost_consti tutions/documents/hf_jp-ii_apc_15041979_sapientia-christiana.html.

John-Paul II, 199o. English: http://www.vatican.va/content/john-paul-ii/en/apost_ constitutions/documents/hf_jp-ii_apc_1508199o_ex-corde-ecclesiae.html.

Leckey, D.R. (2006). The Laity and Christian Education. Apostolicam Actuositatem, Gravissimum Educationis. (Serie: Rediscovering Vatican II). New York/Mahwah, NJ: Paulist Press.

Madero, C. (2018). New thinking about Catholiceducation from Latin America: what the bishops said at Medellin (1968), Puebla (1979), Santo Domingo (1992), Aparecida (2007), International Studies in Catholic Education, 10:1, 30-43, DOI: 10.1080/194225 39.2018.1418944.

McHugh, F.P. (2006). Catholic social thought: its distinctiveness, strengths and weaknesses. In F.P. McHugh, Catholic social thought, renovating the tradition: A key-guide to resources pp. 7-30. Leuven, Belgium: Peeters. 
McHugh, F. P. (2008). Catholic social thought renovating the tradition: a keyguide to resources. Leuven (etc.): Peeters.

O'Malley, J.W. 1979. Praise and Blame in Renaissance Rome. Rhetoric, Doctrine, and Reform in the Sacred Orators of the Papal Court, c. 1450-1521. Duke Monographs in Medieval and Renaissance Studies number 3. Durham, North Carolina: Duke University Press.

O'Malley, J.W. (2008). What Happened at Vatican II. Cambridge, MA / London, England: Harvard University Press.

Paul vi, 1965. Declaration on Christian Education: Gravissimum Educationis. English: http://www.vatican.va/archive/hist_councils/ii_vatican_council/documents/ vat-ii_decl_19651028_gravissimum-educationis_en.html (1965); Latin: http://www .vatican.va/archive/hist_councils/ii_vatican_council/documents/vat-ii_decl_ 19651028_gravissimum-educationis_lt.html (1965).

Paul VI, 1964. Dogmatic Constitution on the Church: Lumen Gentium. http://www .vatican.va/archive/hist_councils/ii_vatican_council/documents/vat-ii_const_ 19641121_lumen-gentium_en.html (1964).

Paul VI, 1965. Pastoral Constitution: Gaudium et Spes. English: http://www.vatican .va/archive/hist_councils/ii_vatican_council/documents/vat-ii_const_19651207_ gaudium-et-spes_en.html.

Paul VI, 1965. Decrete on Laity: Apostolicam Actuositam. English: http://www.vatican .va/archive/hist_councils/ii_vatican_council/documents/vat-ii_decree_19651118_ apostolicam-actuositatem_en.html.

Paul VI, 1965. Decree on the adaptation and renewal of religious life: Perfectae Caritatis. English: http://www.vatican.va/archive/hist_councils/ii_vatican_council/ documents/vat-ii_decree_19651028_perfectae-caritatis_en.html.

Paul VI, 1967. Populorum Progressio. http://w2.vatican.va/content/paul-vi/en/encycli cals/documents/hf_p-vi_enc_26o31967_populorum.html (1967).

Paul vi, 1965. Dignitatis Humanae. English: http://www.vatican.va/archive/hist_coun cils/ii_vatican_council/documents/vat-ii_decl_19651207_dignitatis-humanae_ en.html.

Pius XI. Divini Illius Magistri. Retrieved from http://w2.vatican.va/content/pius-xi/en/ encyclicals/documents/hf_p-xi_enc_31121929_divini-illius-magistri.html (1929).

Pollefeyt, D \& Bouwens, J. 2010. 'Framing the identity of Catholic schools: emperical methodology for quantitive research on the Cattholic identity of an edication institute.' International Studies in Catholic Education. Vol. 2, No. 2, October 2010, 193-211.

Ratzinger, J. 1966. 'De bisschoppelijke collegialiteit-Een theologische beschouwing. In: G. Baraúna, O.F.M. (Ed.). De Kerk van Vaticanum II. Commentaren op de Constitutie over de Kerk. 2 Vol. Deel 2. Bilthoven: Nelissen.

Ratzinger, J. 20o9. Theological Highlights of Vatican II. (Introduction by Thomas P. Rausch, S.J.). New York / Mahwah: Paulist Press.

Schillebeeckx, E. 1964. Het Tweede Vaticaans Concilie. 2 Vol. Den Haag: Lannoo. 
Searle, J.R. 1976. 'A Classification of Illocutionary Acts'. Language in Society, Vol. 5, No. 1: pp. 1-23. Cambridge / New York: Cambridge University Press.

Searle, J.R. 199o. Speech Acts. An Essay in the Philosophy of Language. Cambridge / New York: Cambridge University Press.

Siebenrock, R. 2005. 'Theologisches Kommentar über die christliche ErziehungGravissimum Educationis'. In: Hünermann, P, Hilberath, B.J., Bausenhart, G. (eds.), Herders Kommentar zum Zweiten Vatikanischer Konzil. Vol. 3: pp. 555-59o. Herder: Freiburg in Breisgau.

Stam, A.J. 2008. The Church in Relation to the World: A Conceptual Analysis of the Church World Relationship and a Study of the Use of Performative Language and Discursive Strategies in Three Documents of the World Council of Churches' Faith and Order Commission. Delft: Eburon.

Stockman, R. 2015. Christelijke identiteit: een utopie? Kalmthout: Pelckmans Uitgeverij. Van de Ven, J.A. 1993. Ecclesiologie in context. Kampen: Kok: pp. 51-65.

Vigotskij, L., Thought and Language. Newly revised by Al Kozulin. Cambridge, Ma., London, England: Miт Press 2000.

Watson, F. 2010. 'The Scope of Hermeneutics'. In Colin E. Gunton (ed.), The Cambridge Companion to Christian Doctrine. London: Cambridge University Press.

Whittle, S., ed. (2017). Vatican II and new thinking about Catholic education: the impact and legacy of Gravissimum Educationis. Oxon/New York: Routledge.

\section{Relating Publications}

Congregation for Catholic Education 2014. Educating Today and Tomorrow. A renewing Passion. Instrumentum Laboris. Vatican City.

Congregation for Catholic Education 2015. Educating Today and Tomorrow. A renewing Passion. Challenges, Strategies and Perspectives that emerge from the Responses to the Questionnaire of the Instrumentum Laboris. Vatican City. 


\section{Appendix Speech Acts in Gravissimum Educationis}

\begin{tabular}{|c|c|c|}
\hline Paragraphs & Codes $^{a}$ & Key fragments \\
\hline $\begin{array}{l}\text { Gravissimum } \\
\text { Educationis }^{\mathbf{b}}\end{array}$ & $\operatorname{Fde}(P), \operatorname{Fre}(P)$ & $\begin{array}{l}\text { As a declaration Gravissimum Educationis } \\
\text { aims to change lives }[\operatorname{Fde}(\mathrm{P})] \text { by its contents } \\
{[\operatorname{Fre}(\mathrm{P})]}\end{array}$ \\
\hline Exordium & $\operatorname{Fde}(P), \operatorname{Fre}(P)$ & $\begin{array}{l}\text { Fde }(\mathrm{P}) \text { : Declaration on Christian education } \\
\text { Gravissimum Educationis proclaimed by His } \\
\text { Holiness Pope Paul VI ... }\end{array}$ \\
\hline Introduction & $\begin{array}{l}\text { Fde }(P), \operatorname{Fre}(P), \operatorname{Fco}(\mathrm{P}) \\
\operatorname{Fex} /+(\mathrm{P})^{\mathrm{c}}\end{array}$ & $\begin{array}{l}\text { Fco }(\mathrm{P}) \text { : The Church commits herself to the } \\
\text { eminent relevance of education ... } \\
\text { Fex/+(P): ... how extremely important } \\
\text { education is [Lat.: Gravissimum Educationis } \\
\text { momentum] }\end{array}$ \\
\hline $\begin{array}{l}\text { 1. The meaning of } \\
\text { the Universal } \\
\text { Right to an } \\
\text { Education }\end{array}$ & $\begin{array}{l}\text { Fde }(P), \operatorname{Fre}(P) \\
\text { Fdi.pre }(\mathrm{P}), \operatorname{Fdi} \cdot \operatorname{app}(\mathrm{P})\end{array}$ & $\begin{array}{l}\text { Fdi.pre }(\mathrm{P}) \text { : All men of every race, condition } \\
\text { and age, since they enjoy the dignity of a } \\
\text { human being, have an inalienable right to an } \\
\text { education. } \\
\text { Fdi.app }(\mathrm{P}) \text { : Political and church leaders, } \\
\text { governance in society and church and } \\
\text { (Catholic) educators are exhorted to make } \\
\text { possible and maintain moral and religious } \\
\text { education for all children. }\end{array}$ \\
\hline $\begin{array}{l}\text { 2. Christian } \\
\text { Education }\end{array}$ & $\begin{array}{l}\text { Fde }(P), \operatorname{Fre}(P), \\
\text { Fdi.app }(\mathrm{P}), \text { Fdi.pre }(\mathrm{P})\end{array}$ & $\begin{array}{l}\text { Fdi.app }(\mathrm{P}) \text { : Priests are exhorted to create } \\
\text { conditions for and implement for all } \\
\text { Christians and in particular the youths } \\
\text { their right on Christian education ... } \\
\text { Fdi.pre }(\mathrm{P}) \text { : All Christians are entitled to be } \\
\text { raised as a Christian. }\end{array}$ \\
\hline
\end{tabular}

\footnotetext{
a NB As we stated above all paragraphs because of the specific type of text are labelled by the features: $\operatorname{Fde}(\mathrm{P}), \operatorname{Fre}(\mathrm{P})$ in italics. So not in every paragraph we show key fragments of these.

b Cf. corresponding paragraphs.

c This speech act frequently is biased in paragraphs; we'll give a few examples in some cases.
} 
(cont.)

Paragraphs Codes Key fragments

3. The Authors of Education

4. Various Aids of Christian Education

5. The Importance of Schools
Fde $(P)$, Fre $(P)$, Fdi.pre $(\mathrm{P})$, Fdi.pre $(\mathrm{P}), \mathrm{Fco}(\mathrm{P})$, Fdi.app $(\mathrm{P}), \mathrm{Fex} /+(\mathrm{P})$

$\operatorname{Fde}(P), \operatorname{Fre}(P), \operatorname{Fco}(\mathrm{P})$, Fdi.app $(\mathrm{P})$

Fde $(P), \operatorname{Fre}(P)$, Fdi.pre $(\mathrm{P})$, Fdi.app $(\mathrm{P}), \mathrm{Fex} /+(\mathrm{P})$
Fdi.pre(P): Education purports the preparation on life in society and on Christian existence.

Fdi.pre(P): By way of a description, that actually serves as indirect speech acts, a number of obligations of parents regarding raising their children are stated ... Fco(P): The role of the Church regarding education is specified in a number of commitments "announcing the way of salvation to all men ..."

$\mathrm{Fex} /+(\mathrm{P})$ : "they are bound by the most serious obligation [Lat.: gravissima obligatione] to educate their offspring ..."

Fdi.app $(\mathrm{P})$ : ... the State, is encouraged to create conditions to make possible Christian upbringing and education, in accordance with the subsidiarity principle.

Fco(P): By her council fathers the Church commits herself to deploy all her own available sources ...

Fdi.app (P): ... which as an exhortation at the same time means an obligation for church servants ...

Fdi.pre(P): In a note is referred to Divini Illius Magistri, which encyclical emphasized and claimed the autonomy of the school ... Fdi.app $(\mathrm{P})$ : The parish church establishes a center in and by which various types of associations find their home ... Fex/+(P): The teacher's role, for which specific job-requirements are essential, ... is therefore called important, but also beautiful ... (pulchra)... 
6. The Duties and Rights of Parents
7. Moral and Religious Education in all Schools
Fde $(P), \operatorname{Fre}(P)$, Fdi.pre $(\mathrm{P})$, Fdi.app $(\mathrm{P})$ Fex/- (P)
Fde $(P), \operatorname{Fre}(P), \mathrm{Fex} /+(\mathrm{P})$, Fdi.pre $(\mathrm{P}), \mathrm{Fco}(\mathrm{P})$

\section{Catholic Schools}

Fdi.pre $(\mathrm{P})$ : While having an inalienable right and duty to educate, parents' freedom of school choice is claimed towards the State, in addition to the facilitating support of the latter.

Fdi.app(P): The Sacred Synod exhorts the Christian faithful to assist in and help in the fulfilment of good education and (especially moral) forming. Fex/- (P): A state's monopoly in schooling is rejected for this is contrary to the natural rights of the human person ...

Fex/+(P): "Feeling very keenly the weighty responsibility of diligently caring for the moral and religious education" at nonCatholic schools.... / The Church praises the authorities that guarantee religious freedom and facilitate material conditions ... Fco $(\mathrm{P}): \ldots$ the Church promises the deployment of priests, teachers, but also fellow students, "who give [the youths] the doctrine of salvation [...] and provide spiritual aid" ...

Fdi.pre(P): Parents should demand State's guaranties of religious freedom, etc., if necessary ...

Fdi.pre(P): The Church claims the right of establishment and administration of the Catholic schools ...

Fco(P): ... committing to create an

"atmosphere animated by the Gospel spirit" to the benefit of all people $/ . .$. and emphasizes the importance for the profane culture, by expressing her commitment to dialogue ... Fdi.app $(\mathrm{P})$ : With respect for both roles, teachers and parents must seek synergy in education and upbringing ... 
(cont.)

Paragraphs Codes Key fragments

9. Different types $F d e(P), \operatorname{Fre}(P), \mathrm{Fco}(\mathrm{P})$, of Catholic Fdi.app $(\mathrm{P}), \mathrm{Fex} /+(\mathrm{P})$ Schools

10. Catholic Colleges and Universities

11. Faculties of Sacred Sciences

12. Coordination to be Fostered in Scholastic Matters Fdi.app $(\mathrm{P})$, Fex $/+(\mathrm{P})$
Fde $(\mathrm{P})$ : The church meeting explains and declares teacher's work as a vocation and an apostolate ...

Fco(P): The Sacred Synod guarantees multiplicity depending on local circumstances of Catholic schools ... Fex/+(P), ... the Church cherishes affection for schools also attended by non-Catholic pupils or students ...

Fdi.app $(\mathrm{P})$ : She calls on stakeholders to help with school's organisation and design, with special attention for underprivileged and non-believers.

Fde $(P), \operatorname{Fre}(P), \operatorname{Fco}(\mathrm{P}), \quad$ Fex $/+(\mathrm{P})$ : The Church cherishes higher education with great care, especially Catholic universities and Catholic faculties.

Fco $(\mathrm{P})$ : ... she pursues to the legitimacy of Catholic universities

Fdi.app $(\mathrm{P})$ : She recommends to spread these Catholic colleges and universities over as many areas as possible ...

Fco(P): The Church expects much from the 'sacred' faculties and therefore entrusts them with the training of priests and priest-teachers.

Fdi.pre(P): These faculties are instructed to deepen and spread the Christian heritage and to speed up dialogue with the separated fellow Christians and the non-Christians. To that end they have to update their statutes and curricula.

Fdi.app $(\mathrm{P})$ : Coordination between Catholic schools and with non-Catholic schools should be promoted and fostered by all means. 
(cont.)

\begin{tabular}{|c|c|c|}
\hline Paragraphs & Codes & Key fragments \\
\hline Conclusion & $\begin{array}{l}\text { Fde }(P), \operatorname{Fr} e(P), \operatorname{Fdi} . \operatorname{app}(\mathrm{P}) \\
\text { Fex } /+(\mathrm{P}), \text { Fdi.pre }(\mathrm{P})\end{array}$ & $\begin{array}{l}\text { Fdi.app (P): The Sacred Ecumenical Council } \\
\text { (S. Synodus) entreats young people, urging } \\
\text { them to take up the important work of } \\
\text { education, especially in areas where there } \\
\text { are few teachers. } \\
\text { Fex / + (P): She expresses her gratitude to } \\
\text { all educators and teachers because of their } \\
\text { important work and praises this work. } \\
\text { Fde (P): After obtaining agreement with } \\
\text { the text of Gravissimum Educationis of } \\
\text { the Council Fathers, Pope Paul vi gives his } \\
\text { approval 'by fixed ordinance' by virtue of his } \\
\text { apostolic authority and order [Lat. Iubemus] } \\
\text { promulgation. } \\
\text { Fdi.pre(P): Id. }\end{array}$ \\
\hline Notes / references & Fdi.pre(P) & $\begin{array}{l}\text { Implicit prescriptive references and notes. } \\
\text { Cf. supra: section Notes. }\end{array}$ \\
\hline
\end{tabular}

